\title{
Investigation of The Relationship Between Migration, Unemployment and Growth in the OECD Countries with Panel ARDL Technique
}

\author{
Serdar ÖZTÜRK* $\quad$ Sevil ÖZDİL**
}

\begin{abstract}
Economic growth is typically accompanied by migration. Both factors are great important in the growth process. This study empirically examines the interaction between migration and economic conditions of the target country.

In the period of 1990-2016, the panel data was analyzed by panel ARDL technique by using he annual data set in 19 OECD countries. Short and long term results were obtained. The long-term results show that migration flows contribute to the economic growth of host countries. Short-term results showed that migration flows had a negative impact on growth. On the other hand, as expected, in the long run, while the increases in employlment increase the GDP per capita, each increase in unemployment rate decreases GDP per capita. It is also possible to say that the migration is affected by the economic conditions of the host countries.
\end{abstract}

Key Words: International Migration, Growth, Unemployment, Panel ARDL, OECD

JEL Classification: F22, O47, B22, C33, O50

\section{OECD Ülkelerinde Göç, İşsizlik ve Büyüme Arasındaki İlişkinin Panel ARDL Tekniği ile İncelenmesi}

\section{$\ddot{O} Z$}

Ekonomik büyümeye tipik olarak göç de eşlik etmektedir. Büyüme sürecinde her iki faktör de büyük önem taşımaktadır. Bu çalışma, hedef ülkenin göç ve ekonomik koşulları arasındaki etkileşimini ampirik olarak incelemektedir.

Bu doğrultuda çalışma, 1990-2016 dönemi 19 OECD ülkesi için panel ARDL tekniği ile incelenmiştir. Kısa ve uzun dönem olmak üzere iki sonuç elde edilmiştir. Sonuçlar, göç aklşlarının uzun dönemde ev sahibi ülkelerin ekonomik büyümesine katkısının olduğunu göstermiştir. Kısa dönem sonuçları ise, göç akışlarının büyümeyi olumsuz etkilediğini göstermiştir. Diğer yandan beklenildiği üzere uzun dönemde, istihdamdaki artışlar kişi başı GSYH'yi artırırken işsizlik oranlarındaki her bir artış kişi başı GSYH'yi azaltmaktadır. Ayrıca göçün, ev sahibi ülkelerin ekonomik koşullarından etkilendiğini de söylemek mümkündür.

Anahtar Kelimeler: Uluslararası Göç, Büyüme, İssizlik, Panel ARDL, OECD

JEL Sinıflandirması: F22, O47, B22, C33, O50

\section{INTRODUCTION}

Migrants are the main source of population growth in OECD countries. In recent years, they have contributed more than natural population growth, especially

\footnotetext{
*Prof. Dr., Nevşehir Hacı Bektaş Veli Üniversitesi İktisadi ve İdari Bilimler Fakültesi, İktisat Bölümü. serdarozturk@nevsehir.edu.tr, ORCID Bilgisi: 0000-0003-0650-0244

** Doktora Öğrencisi, Nevşehir Hacı Bektaş Veli Üniversitesi Sosyal Bilimler Enstitüsü, İktisat Bölümü. sevilozdl@gmail.com ,ORCID Bilgisi: 0000-0002-4321-4899
} 
in European countries. Given the aging population and the declining working-age population, migrations are likely to continue at an increasing rate in the coming years (Bouptane et al., 2011: 2).

It is possible to say that the reason for the migration flows have changed a few decades ago. In this process, relatively real wages and employment are some of the main drivers of international migration. Again, the effects of different welfare regime of states is one of these elements. Social services, high levels of benefit and high tax levels are common features of many OECD countries. Hence, states' welfare levels may play an important role in the decision of immigrants (Ruyssen et al., 2012: 176-177). First of all, migrants acting for familial reasons constitute the largest group of immigrants to the OECD region and represent three quarters of annual entries in some countries (OECD, 2017). In terms of composition, migration from Central and Eastern Europe to Western Europe has been seen to be accumulated in the European Union (Pedersen et al., 2008: 1161). In case the host country presents an the appropriate institutional system, migrants and refugees can transfer their talents, skills and capital in a way that contributes to in the long run economic growth. On the other hand, there is evidence that international migration promotes economic growth in host countries through various channels such as innovation, capital accumulation, human capital, foreign trade and domestic demand. Therefore, this situation brings the acceleration of economic growth in the countries receiving immigration. On the other hand, in cases where unemployment is high in the target country, immigrants and refugees entering the labor market may also increase the unemployment rate and lower the average wage level. In such cases, informal employment in the target country tends to increase (Gur, 2017: 712).

This article aims to see the economic impact of migrants in host countries. In particular, it is closely related to the aforementioned studies on the internal interaction between migration and the economic conditions of the host country. The paper, contributes to the current literature on the internal interactions between migration and the economic conditions of the host country by using a panel Autoregressive Distributed Lag (ARDL) approach. These analyze are based on a country group framework. Some countries were not included due to insufficient data. In this context, the aim of this study is to examine the dynamics between migration, unemployment and growth for 19 OECD countries in the period 19902016. Panel ARDL approach is a very effective method in terms of showing short and long term parameters. GDP per capita was taken to examine whether migration would contribute to economic growth in the host country. In addition, different employment parameters were used in the host country. First, to examine the interactions between migration and unemployment, the total unemployment rate; secondly, the total employment rate was used instead of the total unemployment rate to control the impact of migrants on labor force participation.

This article is divided into three sections and arranged as follows. The first section provides information on the theoretical framework. In the second section, 
there is a summary of the literature. The third chapter includes data and results used in empirical research. Finally, the fourth section describes the empirical results and interpretations.

\section{I.THEORETICAL FRAMEWORK}

Although there is no formal definition of international migrants, most experts consider an international immigrant independent of immigration or legal status as the person who has changed his or her usual place of residence in his country (refugeesmigrants.un.org). On the other hand, UNESCO of immigration the term, "is a person who is temporarily or permanently living in a country where he is not born and has acquired important social bonds to this country" in the form of. However, according to the policies of some states, this can be a very narrow definition given that a person can be considered an immigrant even when he is born in the country. The definition of a wider immigrant is as follows;

"According to Article 1.1 (a) of the Human Rights Commission Act 1997/15, it is to be understood that the decision to migrate covers all cases taken freely by the person concerned without personal compliance and without interference by an external compelling factor" (www.unesco.org). In this respect, it indicates that the person is an immigrant. It does not refer to other shoes that force or force refugees, displaced or abandoned homes. Migrants are those who make choices about when to leave and where to go; these choices can sometimes be extremely restricted (www.unesco.org). Differentiated variations, definitions of an objective migration are made. Dominant forms of migration are related to these meaning motives; economic, family reunification, refugees, or legal status; such as irregular migration, corrupt migration, free migration. In terms of migration types that express a widespread categorization of exposed international migrants:

- Internal migration; To move within a state, country or continent

- International migration; Moving to a different state, country or continent

- Seasonal migration; Act in response to all seasons or labor or climatic conditions (www.nationalgeographic.org)

- Temporary workers migrants; It is also known as guest workers or overseas contracted employees. They represent people who migrate for a limited period of time to employ and send money to the source country.

- Highly skilled and commercial immigrants; It represents people with managers, managers, professionals, technicians or similar qualifications seeking employment through transnational labor markets for transnational companies and international organizations' skills in moving or scarce internal labor markets. Many countries welcome these immigrants and have special 'talent and work migration' programs to encourage them to come.

- Irregular migrants or undocumented - illegal immigrants; Persons entering a country without the necessary documents and permits, usually seeking employment.

- Forced migration; More broadly, this includes not only refugees and asylum seekers, but also those who have to act because of external factors such 
as environmental disasters or development projects. This migration form has similar characteristics to displacement.

- Family members (or family reunification migrants); People who share family ties participate in people who have entered an immigrant country in one of the categories mentioned above. Many countries in principle recognize the right to family reunification for legal immigrants. Other countries, particularly those with contracted labor systems, deny the right to family reunification.

- Return migrants; They represent people who returned to their own country after a while from another country (http://www.unesco.org).

The number of international migrants has increased significantly in the last 45 years. According to International Organization for Migration (IOM) there are 244 million people who migrated to another country in 2015. This means that one out of thirty people is an immigrant. It was 153 million in 1990 and 84 million in 1970 (www.iom.int, 2018). Migration flows has increased, as seen in a few decades. Given the large demographic and economic imbalances, the likelihood of a fall in these migration flows is unlikely.

According to the OECD migration report, 5 million migrants in 2016 while 4,7 million people entered the OECD countries in 2015. Approximately 1,6 million people applied for asylum in 2016 and 1,5 million of these applications were accepted. Thus, the number of foreign-based populations in Europe increased to about 124 million. In 2016, the maximum number of these asylum applications were made to Germany by 722 thousand people, followed by Italy with 261 thousand people and Italy with 122 thousand people. Again, when looked at the 2016 asylum applications lodged in Turkey decreased by $42 \%$ compared to the previous year was reported to be 78 thousand people. The report also thinking of migrants in Turkey as well as the post-war return of the majority is specified (https://www.gocvakfi.org/, 2017). In 2017, around 258 million people worldwide live outside their home country, and about half of all migrants are in OECD countries. These migration flows increased from 82 million in 1990 to 127 million in 2010. In 2017, more than 5 million people were permanently located in OECD countries. In addition, more than 4 million temporary foreign employees were registered in OECD countries in 2016 in order to overcome their deficiencies and more than 3 million international students enrolled in higher education institutions in one OECD country (OECD, 2017). The OECD report also states that approximately two-thirds of migrants in OECD countries contribute to the steady improvement of the labor market as a business owner. In 2016, the unemployment rate of workers born abroad was $8.3 \%$ among all OECD countries and $12.4 \%$ in European countries. These data are 1.8 and 4.3 points higher than the locals (https://www.gocvakfi.org/, 2017).

\section{LITERATURE}

In order to examine the impact of migration on the host economy, some empirical articles address the problem of internality by using instrumental variable methods, since economic conditions in the target countries may affect migration. 
In general, empirical studies using the spatial correlation approach use earlier information as an instrumental variable about immigrant settlement (Boubtane et al., 2013a: 400). Indeed, Withers and the Pope (1985) used both causality and traditional models to investigate the relationship between immigration and unemployment in the post-war period in Australia. Accordingly, they have found strong evidence of a significant impact on immigration in Australia, but they have not found any causal link from immigration to unemployment. Pope and Withers (1985) examined for Australia, Marr and Siklos (1994) and Islam (2007) investigated Canada. These studies have found evidence that migration does not lead to higher unemployment, but that unemployment in the host country adversely affects migration.

Bencivenga and Smith (1997) have examined how rural-urban migration affects the process of underemployment and capital formation. Accordingly, they emphasized that rural urban migration and underemployment could be source of development and could lead to growth. Pischk and Velling (1997), by using data sets at the country level in the late 1980s, examined the impact of immigrants in Germany on entry into the local labor market and stated that migration had no detrimental effect. Ortega (2000) provides a theoretical justification for the positive effect of migration on labor. In general, empirical studies on the labor market impact of migration in host countries conclude that migration flows do not diminish the expectations of the indigenous labor market.

On the other hand, panel-level studies also examine the impact of immigrants on growth. Angrist and Kugler (2003) used the panel for 18 European countries from 1983 to 1999 and found a negative impact on the labor market employment of migrants. Islam (2007) examined the relationship between unemployment and migration in Canada. There was no evidence that migration had a significant impact on unemployment. Co-integration tests show that there is no increase in total unemployment due to long-term migration. There is also a long-term positive relationship between GDP per capita, migrant rate and real wages. Ortega and Peri (2009), in the period of 1980-2005 in 14 OECD countries using the so-called-shot model of migration did not affect the per capita income. According to a panel data set consisting of 14 OECD countries between 1980 and 1995, Mayda (2010) found that income opportunities in the target country had a positive impact on migration flows. Jean and Jimenez (2011) evaluated the migration and unemployment in 18 OECD countries in the period 1984-2003 and stated that migration had no lasting effect. Boubtane et al. (2013b) empirically examines the interaction between migration and economic conditions of the host country. During the 1987-2009 period, 22 OECD countries used the panel VAR technique using the annual data. According to the findings, while migration movements have a positive effect on GDP per capita, it has been found to have a negative effect on unemployment. As a matter of fact, Bashier and Siam (2014) examined the impact of migrant workers on economic growth in Jordan for the period 1980-2012 using the FMOLS approach. According to the study, empirical findings showed that the variables of real capital and domestic workforce had positive and significant effects on 
economic growth. It is determined that migrant workers have a positive but insignificant effect on economic growth. Dustmann, Frattini and Rosso (2015) analyzed the effect of emigration from Poland on Polish wages. The findings show that migration leads to a slight increase in wages for high- and medium-skilled workers with the highest immigration rates. Examining the contribution of migration to growth for Spain, Mihi-Ramírez et al. (2016) found that the impact of migration on development level was small but positive. Bove and Elia (2017), It has been determined that immigrants living outside their countries of origin generally have a positive impact on real GDP per capita and that the impact of diversity is more consistent in developing countries. Bove and Elia (2017) found that immigrants living outside the countries of origin generally have a positive effect on real GDP per capita, and the impact of diversity is more consistent in developing countries. Investigating the impact of migration on economic growth and human development in selected Sub-Saharan Africa (SSA) countries, Akanbi (2017) found that migration adversely affected human development and economic growth in the region. Škuflić and Vučković (2018), who wanted to analyze the impact of migrants on unemployment rates for the 9 selected EU countries, found that migration increased the unemployment rate in migrant countries. They argued that, in addition to the expected positive effects of unemployment, migration could negatively affect the labor markets of migrant countries. Investigating the known direct relationship between migration and growth, Borjas (2019) argued that migration only had a more beneficial effect on growth when it was made up of highly skilled workers. On the contrary, Esposito (2020), evaluated the impact of immigration on domestic unemployment in the short and long term for a sample of 15 EU countries between 1997-2016, and found that immigration reduces unemployment rates in both the long term and short term.

In the results, there is evidence that migration inputs contribute to the economic growth of the host countries. In most studies, migration has a significant impact on income and unemployment differences between origin and destination country. And the direction of the findings in both the sending and receiving countries is changing.

\section{METHODOLOGY}

\section{A. Method and Data Set}

This study empirically examines the interaction between migration and economic conditions of the host country. Accordingly, Panel ARDL technique was used for 19 OECD countries. For this purpose, annual data covering 1990-2016 period were taken. $g$; 2010 GDP per capita in fixed prices, $m$; migration stocks, $u$; 15-64 years of unemployment rate as percentage. $e$; gives labor statistics. All variables were taken from the OECD database. In this article, panel ARDL model developed by Pesaran, Shin and Smith (1999) was used. Panel ARDL technique is an efficient model by modeling both short and long term at the same time and gives results of error correction mechanism which shows how long the deviations occurred between the variables will disappear. Another feature of the panel ARDL 
is that it produces results by permitting the heterogeneity of the coefficients. The panel ARDL model for the relationship between migration, unemployment, per capita GDP and employment is as follows:

$$
g_{i t}=\alpha_{i}+\sum_{j=1}^{p} b_{1 i j} g_{i t-j}+\sum_{j=0}^{p} b_{2 i j} m_{i t-j}+\sum_{j=0}^{p} b_{3 i j} u_{i t-j}+\sum_{j=0}^{p} b_{3 i j} e_{i t-j}+v_{i t}
$$

Where $\mathrm{i}=1,2,3$, un, $\mathrm{N}$ refers to the number of sections and $\mathrm{t}=1,2,3,1 \mathrm{~s}, \mathrm{t}$ represents the time dimension. Long-term coefficients are present in this equation where the values of the variables are at the level. Long-term coefficients are obtained. This equation is shown in the figure below.

$$
\begin{gathered}
g_{i t}=\alpha_{i}+\sum_{j=1}^{p-1} b_{1 i j} \Delta g_{i t-j}+\sum_{j=0}^{p} b_{2 i j} \Delta m_{i t-j}+\sum_{j=0}^{p} b_{3 i j} \Delta u_{i t-j}+\sum_{j=0}^{p} b_{3 i j} \Delta e_{i t-j} \\
+\sigma_{i} g_{i t-1}+\varphi_{i} m_{i t}+\theta_{i} u_{i t}+\emptyset_{i} E_{i t}+v_{i t}
\end{gathered}
$$

This equation gives short term coefficients. The " $\Delta$ " sign in the equation refers to the first order difference processor, $\sigma_{i}$ is the error correction factor. This error correction factor, which is statistically significant and negative, shows the long-term relationship between the variables and the economic performance of countries.

\section{B. Empirical Findings}

In this study, the first-generation unit root tests, Im, Pesaran \& Shin (2003) panel unit root test is given. The IPS test is a test that takes into account the heterogeneity of the coefficients of the horizontal sectional units. According to the test, the null hypotheses show that the series contains unit roots. In this context, according to the unit root test results obtained in Table 1, it is determined that per capita GDP contains unit root in I(0) and it is not static; In this context, the cointegration relationship between variables, short and long term coefficient estimates can be obtained with the panel ARDL model.

Table 1: Im Pesaran Shin (2003) Unit Root Test

\begin{tabular}{ccc}
\hline & Level & First Difference \\
\hline $\mathbf{g}$ & $3.4613^{*}(0.999)$ & $97.1703^{*}(0.000)$ \\
$\mathbf{m}$ & $-3.6007^{*}(0.000)$ & - \\
$\mathbf{e}$ & $-2.3311^{*}(0.009)$ & - \\
$\mathbf{u}$ & $-2.2542^{*}(0.012)$ & - \\
\hline
\end{tabular}

Note: Optimum lag length is 2 according to Akaike information criterion. * shows the statistical values of the series indicated by $*$. Values in parentheses represent the probability values.

In the study, each economic indicator (per capita GDP, migration, employment, unemployment) shows the effects on the economic performance of these countries. Therefore, short and long term estimation results of Panel ARDL model are given in Table 2 . 
Table 2. Panel ARDL test results

\begin{tabular}{ccc}
\hline Long-term coefficients & coefficients & t- statistics \\
\hline $\mathbf{m}$ & $-0.02147(0.0000)$ & -9.763073 \\
$\mathbf{~}$ & $-2.61 \mathrm{E}-0(0.0198)$ & -2.340915 \\
$\mathbf{u}$ & $0.00158(0.0291)$ & 2.190773 \\
\hline Error Correction Factor & & \\
\hline ec & $-0.87824(0.000)$ & -10.17363 \\
Short Term Coefficients & coefficients & t- statistics \\
\hline $\mathbf{m}$ & $0.03135(0.0002)$ & 3.752052 \\
$\mathbf{e}$ & $-2.95 \mathrm{E}-0(0.9161)$ & -0.105444 \\
$\mathbf{u}$ & $1.08861(0.7777)$ & 0.282485 \\
$\mathbf{c o n s}$ & $0.09773(0.0000)$ & 8.881599 \\
\hline
\end{tabular}

Accordingly, the error correction mechanism works and the error correction factor corrects the short term imbalances by 0.8 . It is observed that the coefficient is both statistically significant and negative. This shows that there is a cointegration relationship between the variables and the deviations in the short term come to equilibrium in the long run. According to the results of Panel ARDL estimation calculated for 19 OECD countries, each indicator has a long-term effect on GDP per capita. In the short term only the relationship between migration and income is significant. In the long run, a $1 \%$ increase in employment leads to a significant increase of $0.001 \%$ per capita GDP, while each $1 \%$ increase in migration and unemployment rates in the long term decreases GDP per capita by $0.02 \%$ and $2 \%$, as expected. In this case, it is observed that the increase in the unemployment rate in the long-term has a great effect on GDP per capita. On the other hand, each increase in the migration flows negatively affects the per capita GDP of the host countries in the long term, whereas the $1 \%$ increase in the migration flows in the short term increases the per capita GDP by $0.03 \%$. However, there is no significant relationship between economic performance and other variables in the short term.

\section{RESULT}

This study empirically examines internal interactions between migration and economic conditions of the host country. Therefore, a panel ARDL approach was applied in the study based on the data of 19 OECD countries in the period of 19902016. According to the short and long-term effects, the long-term migration flow positively affects the host country's GDP, and in the short-term, migration flows affect the host country's GDP negatively. As studies have shown (Ortega and Peri, 2012; Dolado et al., 1994; Islam, 2007), migration, contributes to economic growth in the host country. In addition, increases in employment in the long term increase per capita income as expected. The results show that immigrants are mainly related to total unemployment, which is a better indication of employment opportunities in the host country. Evidence of a country's ability to receive foreign labor, that is to say, the effects of migration inflows, which are reflected in the GDP per capita growth and total unemployment rate, can be explained for the following reasons.

Excepting compulsory reasons in the host country, the decision to migrate, outweighs the possibility of income, employment opportunities and employment in 
the host country. Migrants 'immigration decisions will be more sensitive to economic conditions, because better economic conditions in the host country increase migrants' attempts to migrate. In particular, this will further encourage migration in host countries with less barriers to migration.

For future research, a number of recommendations are concluded. It is possible to say that more studies are needed to understand the micro foundations of total migration flows. In particular, it is necessary to better understand the nature of migration costs and how migration policies shape these costs. More research is needed to understand migration decisions in response to macroeconomic shocks, particularly between Europe and the regions receiving migration. To be able to produce more comprehensive and developed immigration policies with quantitative criteria; Also all attention and attention should be on the collection of large and homogeneous data at the individual level, coordinating efforts in almost all social sciences. In particular, there is no problem in Turkey, which is an OECD country's immigration policy data makes this even more important.

\section{REFERENCES}

Akanbi, O. A. (2017). Impact of migration on economic growth and human development. International Journal of Social Economics.

Angrist JD, Kugler AD (2003), 'Protective or Counter-productive? Labour Market Institutions and the Effect of Immigration on EU Natives'. Economic Journal, 113: 302-331.

Bencivenga VR, Smith BD (1997), 'Unemployment, Migration, and Growth'. Journal of Political Economy, 105-3: 582-608.

Bashier A, Siam AJ (2014), 'Immigration and Economic Growth in Jordan: FMOLS Approach'. International Journal of Humanities Social Sciences and Education (IJHSSE), 1(9): 85-92.

Borjas G, (2019), 'Immigration and Economic Growth'. National Bureau Of Economic Research, Cambridge, MA 02138.

Boubtane, E., Coulibaly, D., \& Rault, C. (2013a). 'Immigration, unemployment and GDP in the host country: Bootstrap panel Granger causality analysis on OECD countries'. Economic Modelling, 33, 261-269.

Boubtane E, Coulibaly D, Rault C (2013b), 'Immigration, growth and unemployment: Panel VAR evidence from OECD countries'. Documents de Travail du Centre d'Economie de la Sorbonne.

Bove, V., \& Elia, L. (2017). Migration, diversity, and economic growth. World Development, 89, 227 239.

Butler, M. (2017). Investigating the Effects of Migration on Economic Growth in Aging OECD Countries from 1975-2015.

Dolado J, Goria A, Ichino A (1994), 'Immigration, Human Capital and Growth in the Host Country: Evidence from Pooled Country Data'. Journal of Population Economics, 7: 193-215.

Dustmann, C., Frattini, T., \& Rosso, A. (2015). The effect of emigration from Poland on Polish wages. The Scandinavian Journal of Economics, 117(2), 522-564.

Esposito, P., Collignon, S., \& Scicchitano, S. (2020). The effect of immigration on unemployment in Europe: Does the core-periphery dualism matter?. Economic Modelling, 84, 249-258.

GAV (2017), Göç Araştırmaları Vakfı, http://gocvakfi.org/oecd-2017-goc-raporu-yayinlandi/ (28.10.2018).

Gür N, (2017), ' Ülke Deneyimleri Işığında Uluslararası Göç Ekonomisi'. Siyaset, Ekonomi Ve Toplum Araştırmaları Vakf (Seta), Aralık, 224.

Im KS, Pesaran MH, Shin Y (2003), 'Testing for unit roots in heterogeneous panels'. Journal of Econometrics, 115(1): 53-74. 
Islam A (2007), 'Immigration and Unemployment Relationship: Evidence from Canada', Australian Economic Papers, 46: 52-66.

Jean S, Jimenez M (2011), 'The Unemployment Impact of Immigration in OECD Countries'. European Journal of Political Economy, 27: 241-256.

Marr W, Siklos P (1994), 'The Link between Immigration and Unemployment in Canada', Journal of Policy Modeling, 16: 1-26.

Mayda AM (2010), 'International Migration: A Panel Data Analysis of the Determinants of Bilateral Flows', Journal of Population Economics, 23: 1249-1274.

Mihi-Ramírez, A., Ojeda-González, S., Miranda-Martel, M. J., \& Agoh, E. (2016). The contribution of migration to economics growth. Evidence from Spain. Open Economics, 1(1), 124-130.

OECD, (2017), 'A portrait of family migration in OECD countries'. International Migration Outlook 2017.

Ortega F (2000), 'Pareto Improving Immigration in an Economy with Equilibrium Unemployment'. Economic Journal, 110: 92-112.

Ortega F, Peri G (2012), 'The Effect of Income and Immigration Policies on International Migration'. Migration Studies, 1(1), Oxford University Press.

Pedersen PJ, Pytlikova M, Smith N (2008), 'Selection and network effects-Migration flows into OECD countries 1990-2000'. European Economic Review, 52(7): 1160-1186.

Pesaran, M. H., Shin, Y., \& Smith, R. P. (1999). Pooled mean group estimation of dynamic heterogeneous panels. Journal of the American Statistical Association, 94(446), 621-634.

Pope D, Withers G (1985), 'Immigration and Unemployment', Economic Record, 61: 554-563.

Pischke JS, Velling J (1997), 'Employment Effects of Immigration to Germany: An Analysis Based on Local Labor Markets'. Review of Economics and Statistics, 79(4): 594-604.

Ojeda-Gonzalez, S., Mihi-Ramirez, A., Arteaga Ortiz, J., \& Cuenca-Garcia, E. (2018). Spain trade in view of some migratory and economic considerations. Inžinerine ekonomika.

Ruyssen I, Everaert G, Rayp G (2012), 'Determinants and dynamics of migration to OECD countries in a three-dimensional panel framework'. Empirical Economics, 46(1):175-197.

Škuflić, L., \& Vučković, V. (2018). The effect of emigration on unemployment rates: the case of EU emigrant countries. Economic research-Ekonomska istraživanja, 31(1), 1826-1836.

Withers G, Pope, D. (1985), 'Immigration And Unemployment'. Economic Record, 61(173):554-63.

World Migration Report 2018, https://www.iom.int/wmr/world-migration-report-2018.

https://refugeesmigrants.un.org/definitions (11.11.2018).

http://www.unesco.org/new/en/social-and-human-sciences/themes/international migration/glossary/ migrant/ (11.11.2018).

https://www.nationalgeographic.org/activity/introduction-human-migration/ (12.11.2018). 